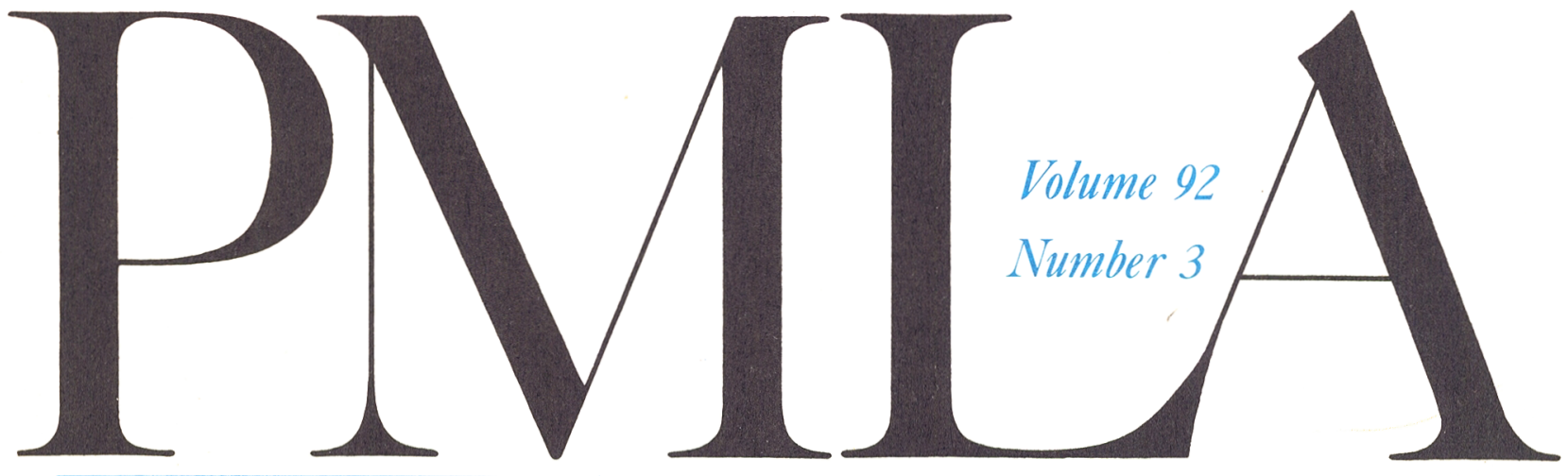

Publications of the

Modern Language Association

of America

\title{
May 1977
}




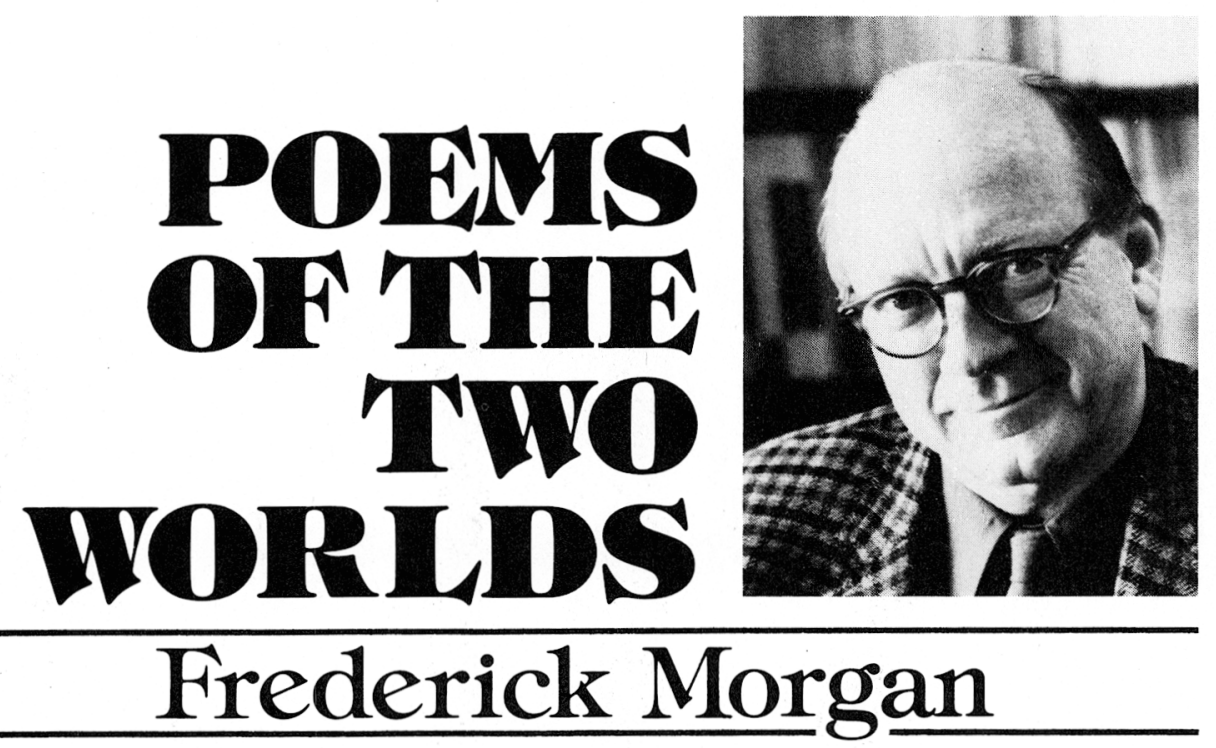

Morgan's second volume of verse flows with the direct personal expression and naturalness that won a National Book Award nomination for his first collection, the critically acclaimed Book of Change (1972). The present collection deals variously with the worlds of life and death, body and spirit, reality and imagination, man and what is beyond man. "There is in this body of work a security, a deep holding, so certain of its accuracy and strength that it can release (and find) a range of feelings of a richness unprecedented in our times." -A. R. Ammons. Morgan is editor of the Hudson Review, of which he was a founder in 1948. Among the periodicals in which his poems have appeared are New Yorker, New York Review of Books, New Republic, Commonweal, American Scholar, and Paris Review.

$$
\text { Cloth, } \$ 7.95 \text {; paper, } \$ 3.95
$$

\section{Books of and about poetry seheduled for publieation}

New and Selected Poems, by Michael S. Harper

On Earth as It Is, poems by Dan Masterson

Seleeted Prose, by Richard Eberhart. The best of his many essays on poetry and poets

Unassigmed Frequencies: Readings in Contemporanty Amenocan Poetry, 1964-76, by Laurence Lieberman. A selection of Lieberman's essays giving a comprehensive, up-to-date portrayal of the chief trends in contemporary American poetry.

Individuals send payment with order. We will pay postage and handling charges.

\section{Univeresity of Illimois Press Urbana, Illinois 61801}




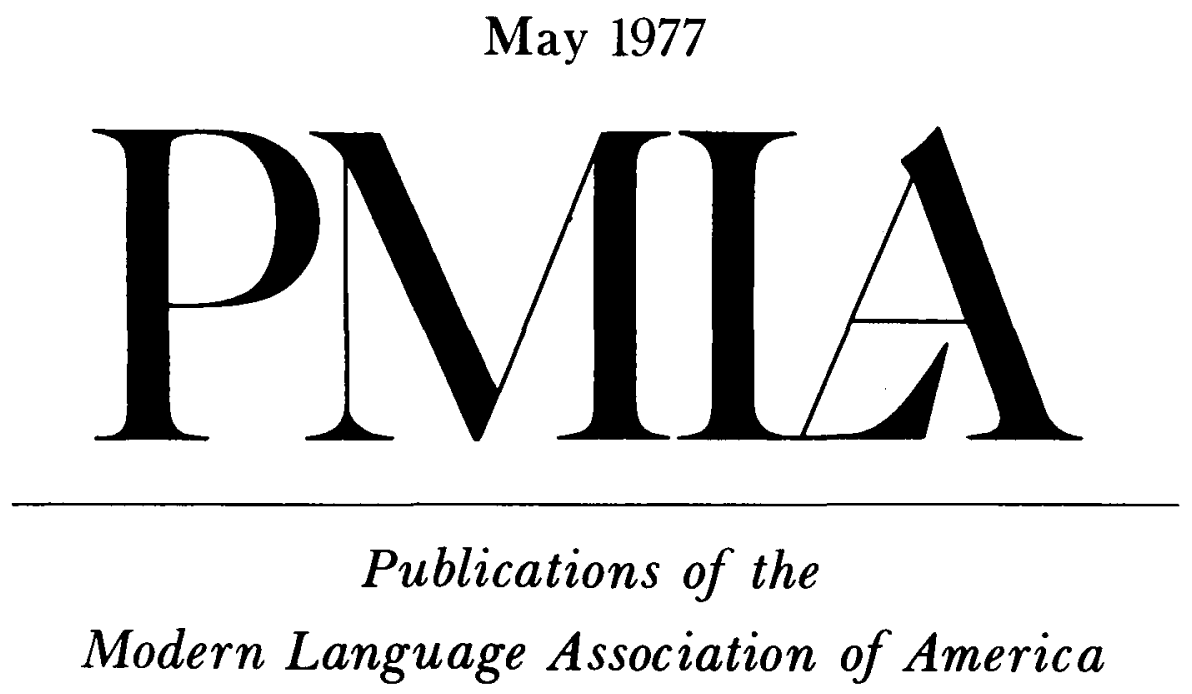

Volume 92

Number 3

PUBLISHED SIX TIMES A YEAR BY THE ASSOCIATION 
The Modern Language Association of America

ORGANIZED 1883

INCORPORATED 1900

\author{
OFFICERS FOR THE YEAR 1977 \\ President: EDITH KERN, Smith College \\ First Vice-President: WaLTER J. ONG, St. Louis University \\ Second Vice-President: Jean A. Perkins, Swarthmore College \\ Executive Director: William D. SchaEFER \\ Deputy Executive Director: Hans RüTIManN
}

\title{
EXECUTIVE COUNCIL
}

For the term ending 31 December 1977

For the term ending 31 December 1978

Mary Ann Caws

Hunter College, City University of New York

Stanley B. Greenfield

SIDONIE CASSIRER

University of Oregon

Mount Holyoke College

THEODORE J. ZIOLKOWSKI

RUTH S. EL SAFFaR

THEODORE J. ZIOLKOWS
Princeton University

University of Illinois, Chicago Circle

EDWARD WASIOLEK

For the term ending 31 December 1979

David J. Delaura

University of Pennsylvania

Carolyn G. Heilbrun

Columbia University

RONALD PAULSON

University of Chicago

Yale University

For the term ending 31 December 1980

GEOFFREY H. HaRTMAN

Yale University

WINFRED P. LEHMANN

University of Texas, Austin

MaRILYN L. WILLIAMSON

Wayne State University

\section{TRUSTEES OF INVESTED FUNDS}

GORDON N. RAY

Guggenheim Foundation, Managing Trustee

\author{
C. Waller BarRetT
}

ROBERT LUMIANSKY

American Council of Learned Societies

$P M L A$ is issued six times a year, in January, March, May, September, October, and November, by the Modern Language Association of America, 62 Fifth Avenue, New York, New York 10011. Membership is open to those persons who are proféssionally interested in the modern languages and literatures. Annual dues, which include subscription to $P M L A$, are based on members' salaries and are graduated as follows: student members, $\$ 10$; unemployed regular members, $\$ 10$; regular members (first 2 years), $\$ 20$; regular members (salary under $\$ 12,000$ ), $\$ 25$; regular members (salary $\$ 12,000-\$ 18,000$ ), $\$ 30$; regular members (salary over $\$ 18,000$ ), $\$ 35$; joint members (with only 1 subscription to $P M L A$ ), $\$ 45$; foreign members, same as regular members.

The subscription price of $P M L A$ for libraries and other institutions is $\$ 30$. A subscription including a bound volume at the end of the year is $\$ 45$, domestic and foreign. Agents deduct $10 \%$ as their fee. Single copies of the January, March, May, and October issues may be obtained for $\$ 5$ each; the November Program issue for $\$ 10$; the September Directory issue for $\$ 15$.

Issues for the current year are available from the MLA Publications Center. Claims for undelivered issues will be honored if they are received within one year of the publication date; thereafter the single issue price will be charged.

For information about the availability of back issues, inquire of Kraus Reprint Co., Millwood, N. Y. 10546; (914) 762-2200. Early and current volumes may be obtained on microfilm from University Microfilms, Ann Arbor, Mich. 48106. Purchase of current volumes on film is restricted to subscribers of the journal.

\section{OFFICE OF PUBLICATION AND EDITORIAL OFFICES}

62 Fifth Avenue, New York, N. Y. 10011 Tel.: 212 741-5588

All communications, including notices of changes of address, should be sent to the Membership Office of the Association at 62 Fifth Avenue, New York, N. Y. 10011. If a change of address also involves a change of institutional affiliation, the Membership Office should be informed of this fact at the same time.

Second-class postage paid at New York, N. Y. and at additional mailing office.

Copyright (C) 1977 by The Modern Language Association of America.

Library of Congress Catalog Card Number 12-32040.

PRINTED IN THE UNITED STATES OF AMERICA BY THE GEORGE BANTA COMPANY, INC., MENASHA, WISCONSIN 


\title{
Contents - May
}

Presidential Address 1976. NORTHROP FrYe . . . . . .

\section{Wordsworth and the Problem of Imaginative Story: The Case of} "Simon Lee." ANDREw L. GRIfFin . . . . . .

\begin{abstract}
Overshadowed by "The Thorn" and "The Idiot Boy," Wordsworth's "Simon Lee" has attracted little attention. It is, however, a complex and ambitious poem, the product of a collision between narrative form and the demands of the imagination. "Simon Lee" does three things: it seeks to wean the reader from his low taste for stories; it displays a dramatic speaker learning to exchange narrative for lyric poetry; and, surprisingly, it undermines the whole proceeding, mourning for the very tales in verse that it abandons. Analysis of the poem from these three points of view sheds light on Wordsworth's ambivalence toward narrative. At the same time it helps us reassemble and relate three competing views of Wordsworth: as evangelist or moral teacher; as dramatist; and as the elegiac poet of the "Ode" and "Tintern Abbey," whose tendency toward self-involution underlies and influences even his attitudes toward audience and genre. (ALG)
\end{abstract}

\section{The Theme of Mutability in the "Ode to Psyche."}

\section{LEON WALDOFF}

\begin{abstract}
A sound basis for interpreting the odes as a sequence, with unity of theme and progression of thought, may be found in the theme of mutability. It is generally acknowledged as central in the other odes but has been neglected in discussions of the "Ode to Psyche." Though this theme is dealt with defensively, it is evident in the tone, in the paradoxical conception of Psyche as a dying immortal, in the imaginative effort to restore her presence and rescue her from the "faint Olympians," and in the final act of internalization. As in the other odes, the answer to the problem of mutability lies in an acceptance of the natural process of which man's life is a part and in a will to adapt. Though Keats would make Psyche the presider over his soul, he is aware that in the end he must preside over his own growth and "Soul-making." (LW)
\end{abstract}

\section{Tennyson's Optics: The Eagle's Gaze.} GERHARD JOSEPH .

\begin{abstract}
The visual focus in Tennyson's poetry moves between particularized objects and hazy vistas. His particularist bent, arising in part from myopia, coincided with the bias of an age that both exalted the Symbol and revered empirical observation. But Tennyson's fears of psychic entrapment within the object and of nature's uncontrollable prolixity inclined him alternatively toward the receding "past" and the distanced "picture." This tendency reinforces itself through the correlative temporal and spatial frames of his poetry: "modern frames" enclose his "pasts"; "casements" focus his "pictures." Tennyson thus exemplifies the Victorian attempt to reconcile particulars and universals, and the "telescopic dualism" of nineteenth-century painting and poetry, wherein detailed foregrounds and indefinite, receding backgrounds are discrete. In Tennyson such a division distinguishes a material world precisely apprehensible through sight and a spiritual one
\end{abstract}


that fades toward diaphaneity. The paradigm for Tennyson's unattainable goal of optical (and epistemological) inclusiveness is "The Eagle." (GJ)

\title{
King Lear and the Decline of Feudalism.
}

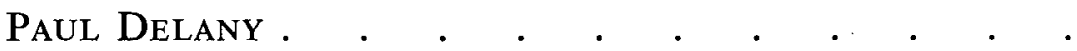

\begin{abstract}
The moral problems that are explored in King Lear can be clarified by viewing them in the context of Shakespeare's history plays and of contemporary social conflicts. Lear and Gloucester share the values of a feudal aristocracy that is threatened by an acquisitive and irreverent bourgeois class; the argument over Lear's train reflects the Tudor monarchs' struggle against maintenance, the right of an aristocrat to keep an armed retinue. The Tudor crisis of the aristocracy had tragic connotations for Shakespeare, and the heroes of his later plays are usually figures of the "old regime." This is not inconsistent with Marx's concept of tragedy, but Shakespeare's humanism should be recognized as nostalgic rather than forward-looking. (PD)
\end{abstract}

\section{God, Satan, and King Charles: Milton's Royal Portraits.}

JoAN S. BENNETT . . . . . . . . . .

Abstract. Between the interpretation in Milton's prose works of the monarchy of Charles I and the portrayal in Paradise Lost of the tyranny of Satan there exists an extensive and complex consistency based on the concept of the divine right of kings, a doctrine that informs the character and world view of Satan as well as of King Charles. In his effort to counteract the Eikon Basilike's picture of Charles as a Christlike martyr-king, Milton drew in Eikonoklastes-albeit in fragmentary form-his own essentially fictional characterization of Charles as a tyrant. This analysis, continued in the Defences, studies Charles's personal heroism, political behavior, delusions about himself, his followers, and his cause and is extensively paralleled in the depiction of Satan. These prose works thus serve as a valuable literary gloss on Paradise Lost - on certain details of imagery and characterization and on Milton's conception of true liberty and revolution. (JSB)

\section{The Parenthetical Function in $A$ la recherche du temps perdu.} SusAN SuleimaN . . . . . . . . . .

Abstract. This essay examines parentheses on the level of individual narrative sequences in $A$ la recherche du temps perdu. A narrative sequence is a limited, linear series of events that can be subsumed under a single label. "Sequence-level parenthesis" may be defined as an independent textual segment inserted between two contiguous moments in the sequence, interrupting its forward movement. The unique feature of Proust's sequence-level parentheses is the multiplicity of functions they fulfill: narrative, interpretive, associative. (1) Parentheses fill in gaps in the story, announce, prepare, or generate events to come, remind us of past events, etc. (2) They qualify or explain specific facts or situations; they also formulate generalizations or laws. (3) Parenthetical associations play a role analogous to that of the metaphor and the phenomenon of involuntary memory: they establish connections (rapprochements) between widely separated textual fragments. To borrow a term used by Proust, Spitzer, and more recently Deleuze, parentheses are the transversales of textual multiplicity. (SS)

\section{"Les Mithologies Pantagruelicques": Introduction to a Study of Rabelais's Quart livre. Alice FIola Berry . . . .}

Abstract. The Quart livre is Rabelais's Inferno. To project his vision of universą catastrophe, Rabelais borrowed from all the voyage literature he knew, from Homer through Cartier, but he drew most from two Old Testament myths. Like 
the story of Jonah, the Quart livre is a voyage down the digestive tract into the sick belly of the whale, of self, of the world-a voyage forecast in Chapter xxxii of the Pantagruel, where Alcofribas enters the giant's mouth, and in Chapter xxxiii, where he descends into Pantagruel's belly to cure him. Rabelais transforms Jonah's story into an account of death and regeneration. He also confers medical value on the story of Moses, who healed the world with the Word of God. As a writer-physician, Rabelais is also a "logotherapist," and his characters strive to emulate Moses' achievement. They too seek the therapeutic word, "le mot de la dive Bouteille." (AFB)

\title{
The Form of Carnival in Under the Volcano.
}

JonAthaN ARAC . . . . . . . . . . .

\begin{abstract}
The variety of moods and techniques and the astonishing erudition of Malcolm Lowry's Under the Volcano have frustrated critical attempts to grasp the work as a unified whole and have fostered instead an emphasis on decoding and explicating. The generic characteristics that Mikhail Bakhtin discerns in the tradition of Menippean Satire, however, provide a fresh and integral interpretation. Bakhtin's description subsumes such formal and thematic aspects of the work as its suppressed comedy, variety of styles, topicality, wide adaptation of other genres, fantastic inventiveness, frequent sharp contrasts and abrupt transitions, scandalous eccentricity, intellectual seriousness, three-leveled world view, utopianism, and psychological abnormality. These apparently heterogeneous characteristics are organized and unified within both Bakhtin's theory and the book's world by the model of carnival festivity. As an annually recurring celebration of change, carnival allows us, furthermore, to understand Lowry's spatializing sense of the book as "trochal," like the regularly turning wheel of a machine. (JA)
\end{abstract}

Forum . . . . . . . . . . . . . . . . . 490

Report of the Executive Director . . . . . . . . 497

Forthcoming Meetings and Conferences of General Interest . . 505

Professional Notes and Comment . . . . . . . . 510 


\title{
PUBLICATIONS OF THE MODERN LANGUAGE ASSOCIATION OF AMERICA Published Six Times a Year
}

Indexes: Vols. 1-50, 1935; 51-60, 1945; 51-79, 1964

\section{EDITORIAL BOARD}

Quentin ANDERson, 1977

Columbia University

ISABEL G. MACCAFFREY, 1979

Harvard University

HANS EICHNER, 1978

University of Toronto

J. Hillis Miller, 1977

Yale University

Claudio Guillén, 1977

University of California, San Diego

Roger SHatTuck, 1978

University of Virginia

ADVISORY COMMITTEE

JONAS A. BARISH, 1980

University of California, Berkeley

JAMES R. KINCAID, 1977

Ohio State University

Peter Brooks, 1980

Yale University

DorRit CoHn, 1979

Harvard University

ANDREw Debicki, 1980

University of Kansas

PaUl De MaN, 1978

Yale University

JoRGE DE SENA, 1978

University of California, Santa Barbara

RichaRd L. LEvin, 1978

State University of New York, Stony Brook

Neal Oxenhandler, 1980

Dartmouth College

Sherman Paul, 1977

University of Iowa

Roy Harvey Pearce, 1979

University of California, San Diego

Robert SCHOLes, 1978

Brown University

STANLEy EUGENe Fish, 1977

Johns Hopkins University

ANGUS S. FletCher, 1978

City University of New York

Patricia Spacks, 1980

Wellesley College

AILEEN WARD, 1978

New York University

John G. Garrard, 1979

University of Virginia

Christof Wegelin, 1978

University of Oregon

Donald R. Howard, 1978

Thomas Whitaker, 1978

Johns Hopkins University

Yale University

Editor: WILLIAM D. SCHAEFER

Managing Editor: JUDY GouldING

\author{
Promotion and Production Manager: \\ JEFFREY HowITT \\ Copyeditor: Claire CoOK
}

\author{
Assistant to Managing Editor: \\ MARGOT RABINER \\ Administrative Assistant: RosLYN ScHLoss
}

\section{A STATEMENT OF EDITORIAL POLICY}

$P M L A$ publishes articles on the modern languages and literatures that are of significant interest to the entire membership of the Association. Articles should therefore normally: (1) employ a widely applicable approach or methodology; or (2) use an interdisciplinary approach of importance to the interpretation of literature; or (3) treat a broad subject or theme; or (4) treat a major author or work; or (5) discuss a minor author or work in such a way as to bring insight to a major author, work, genre, or critical method. Articles of fewer than 2,500 or more than 12,500 words are not normally considered for publication.

Only members of the Association may submit articles to $P M L A$. Each article submitted will be sent to at least one consultant reader and one member of the Advisory Committee. If recommended by these readers it will then be sent to the members of the Editorial Board, who meet every three months to discuss such articles and assist the Editor in making final decisions.

Submissions, prepared according to the second edition of the MLA Style Sheet, should be addressed to the Editor of $P M L A, 62$ Fifth Avenue, New York, New York 10011. Only an original typescript, not a photocopy or carbon, should be submitted. 